\title{
WYKORZYSTANIE RAM JAKOŚCI M.J. EPPLERA DO EWALUACJI JAKOŚCI INFORMACJI SERWISÓW INTERNETOWYCH PWSZ
}

DOI: 10.33141/po.2019.09.07

\section{Marcin Krzesaj}

\section{Wprowadzenie}

W literaturze przedmiotu dostępne są nieliczne modele umożliwiające ocenę jakości informacji znajdujących się w sieci Internet. Większość tych publikacji koncentruje się na dokonywaniu ogólnej oceny funkcjonalności serwisów internetowych traktowanych jako pewien system, tzn. na ocenie jakości działania całego systemu. Należy założyć, że serwis WWW (ang. World Wide Web) stanowi szczególny rodzaj hipermedialnego systemu informacyjnego (Czerwiński, Krzesaj, 2018, s. 65-71). Mając na uwadze ten fakt, można wyróżnić dwa główne kryteria podziału modeli oceny jakości strony WWW: liczbę elementów (szczegółowość modelu) i hierarchię ważności elementów podlegających ocenie (centryczność modelu) (Czerwiński, Krzesaj, 2014, s. 90).

Ze względu na stopień szczegółowości przyjętego modelu oceny można wymienić: model biblioteki cyfrowej (Fuhr i in., 2007) oraz holistyczny model biblioteki cyfrowej (Zhang, 2010, s. 88-110). Hierarchię ważności elementów podlegających ocenie uwzględnia przykładowo model stawiający $\mathrm{w}$ centrum zainteresowania użytkownika strony WWW (Xie, 2006, s. 433-452) lub model stawiający $\mathrm{w}$ centrum zainteresowania użytkownika i kolekcję danych (Saracevic, 2004). W kontekście przedstawionych modeli oceny jakości informacji należy wymienić ramy jakości informacji zaprezentowane przez M.J. Epplera (2001, s. 329-346). Ramy te mają charakter normatywny, dzięki czemu można je wykorzystać do oceny jakości informacji w różnych obszarach, w tym oceny jakości witryn internetowych. Ich uniwersalność potwierdziły analizy studiów przypadków zarządzania jakością informacji w wielu korporacjach.

W praktyce ocena jakości informacji wykorzystuje elementy z modeli oceny jakości witryny internetowej odnoszące się do wybranych obszarów, np. treści, użyteczności, doskonalenia serwisu. Ocena jakości informacji na witrynie WWW może być dokonywana na podstawie kryterium przedmiotowego (wybrane zasoby informacyjne), podmiotowego (dokonywana przez konkretne osoby, instytucje, organizacje) lub podmiotowo-przedmiotowego (określone podmioty oraz wybrane zasoby informacyjne) (Czerwiński, Krzesaj, 2018, s. 78).

Celem artykułu jest określenie i ocena jakości informacji w serwisach internetowych Państwowych Wyższych Szkół Zawodowych (PWSZ) w Polsce z wykorzystaniem ram jakości informacji M.J. Epplera. Na możliwość wy- korzystania witryn PWSZ do badania jakości informacji wskazały badania pilotażowe przeprowadzone w lipcu 2018 roku (Krzesaj, 2019). Potwierdziły one zasadność doboru określonych wskaźników internetowych do pomiaru określonych kryteriów jakości informacji w obszarze jakości mediów w modelu M.J. Epplera (rys. 1). Zakładając, że witryny badanych uczelni zawodowych powinny udostępniać zbliżony zakres informacyjny, możliwe jest porównanie poziomu jakości informacji badanych stron. Ponadto uwzględnione podmioty stanowią wszystkie jednostki jednorodnej populacji. Jednym z głównych obszarów działalności szkół wyższych jest proces kształcenia studentów. Zakres i sposób umieszczania informacji na witrynach PWSZ leży w gestii władz uczelni i nie jest ustawowo zdefiniowany (oprócz obowiązku udostępniania informacji publicznej na stronach BIP), co pozwala na kształtowanie udostępnianych treści zgodnie z przyjętą strategią informacyjną uczelni. Niezależnie od przyjętej strategii, uczelnia powinna jednak udostępniać wszelkie informacje niezbędne $\mathrm{w}$ procesie kształcenia studentów, co uzasadnia przyjęte założenie co do zbliżonego zakresu informacyjnego witryn w tym zakresie.

Ocenę przeprowadzono ponadto z perspektywy użytkownika witryny (studenta, nauczyciela akademickiego), a obszarami podlegającymi ewaluacji są jakość treści oraz jakość mediów. Ogólna ocena jakości treści postrzeganej z perspektywy potencjalnego użytkownika ma na celu ustalenie, czy informacje dostępne na witrynie są zbieżne z potrzebami informacyjnymi studenta. Natomiast uzyskane wyniki odnoszące się do obszaru jakości mediów pozwalają na ocenę procesów i infrastruktury odpowiedzialnej za dostarczanie informacji w Internecie.

Na wstępie artykułu opisano ramy jakości informacji M.J. Epplera, które posłużyły do operacjonalizacji kryteriów oceny jakości informacji oraz wyboru metody oceny jakości informacji na witrynie internetowej. Następnie przedstawiono metodę badania. Uzyskane oceny poszczególnych kryteriów, dokonane przez studentów według sprecyzowanych wytycznych w ankiecie, posłużyły do utworzenia rankingu jakości informacji na witrynach PWSZ w Polsce. Ranking ten odnosi się do obszaru jakości treści i prezentuje perspektywę oceny jakości informacji użytkownika witryny i jego potrzeb informacyjnych. Natomiast pomiar wskaźników internetowych umożliwił analizę i ocenę kryteriów jakości informacji w obszarze jakości mediów. 
Na podstawie uzyskanych wyników stworzono kartę wyników (scorecard). Karta wyników wpisana w strukturę ram M.J. Epplera może być wykorzystana w jednym z etapów zarządzania jakością informacji. Pozwala ona na monitorowanie jakości witryn internetowych $\mathrm{w}$ dwóch obszarach: jakości treści oraz jakości mediów. Zarządzający witryną mogą wykorzystać kartę wyników do identyfikacji ewentualnych obszarów do poprawy. Rozpoznanie luk w jakości informacji pozwoli na wdrożenie procedur ją udoskonalających.

\section{Ramy jakości informacji w Internecie}

I dentyfikacji kryteriów oceny jakości informacji dokonano w oparciu o uproszczone ramy jakości informacji, zaproponowane przez M.J. Epplera (2001, s. 334). W rozważaniach teoretycznych ich autor posiłkował się ponad dwudziestoma różnymi modelami jakości informacji. Definiuje on problemy z jakością informacji jako sytuację, w której obszar treści lub mediów nie spełnia potrzeb stawianych przez użytkowników, producentów lub administratorów danego systemu informacyjnego (Eppler, 2006, s. 45). Ramy jakości informacji mają przy tym charakter normatywny, co pozwala na ich zaadaptowanie w obszarze problemów z jakością informacji na witrynach WWW.

Uproszczone ramy odzwierciedlają cztery widoki jakości informacji powiązane ze sposobem grupowania kluczowych kryteriów jakości w wymiary (rys. 1): relewantność informacji, rzetelność informacji, zoptymalizowany proces, niezawodna infrastruktura. Pierwsze dwa wymienione wymiary odnoszą się zatem do jakości treści informacji (kryteria podlegają subiektywnej ocenie użytkownika informacji). Dwa kolejne wymiary mają związek z jakością mediów, tzn. procesów i infrastruktury, za pomocą których informacja jest dostarczana (kryteria podlegają obiektywnej ocenie za pomocą określonych narzędzi).

\section{Narzędzia do pomiaru jakości informacji na stronach WWW}

$\mathrm{K}$ onceptualny model pomiaru jakości informacji podali B. Stvilia i inni (2007). Model zawiera trzy kategorie badanych cech jakości informacji: wewnętrzną, kontekstową oraz reputacyjną. Model ten może stanowić podstawę do opracowania konkretnych modeli pomiaru jakości informacji dla wielu różnych konfiguracji uwzględniających specyfikę branżową, lecz nie zawiera gotowego zestawu metod pomiarowych.

Do wyznaczania miar poszczególnych kryteriów jakości informacji dostępne są narzędzia służące do przeprowadzenia badania ankietowego. Kompletne narzędzie pod nazwą IQA do oceny wszystkich cech stworzyli Y.W. Lee, D.M. Strong, B.K. Kahn i R.Y. Wang. Powstało ono w wyniku zastosowania pełnej procedury obejmującej trzy następujące etapy: etap budowania kwestionariusza, badania pilotażowe oraz pełne badania (Lee i in., 2002). Dość liczne badania wskazują na wykorzystanie kwestionariuszy ankietowych do oceny jakości informacji dotyczących zdrowia i medycyny w serwisach WWW (Gagliardi, Jadad, 2002; Bernstram i in., 2005). Do takich narzędzi należą między innymi kwestionariusz ankietowy DISCERN i EQIP. Przykładowo J. Kaicker, V. Borg Debono, W. Dang, N. Buckley i L. Thaban (2010) dokonali oceny jakości serwisów WWW poruszających tematykę chronicznego bólu z wykorzystaniem narzędzia DISCERN. Z kolei K. Gkouskou, A. Markaki, M. Vasilaki, A. Roidis i I. Vlastos (2011) zaprezentowali wyniki badania jakości informacji żywieniowych $\mathrm{z}$ wykorzystaniem narzędzi EQIP i DISCERN.

Do pomiaru i oceny jakości informacji dość często wykorzystuje się ponadto metody automatycznych procedur (techniczne) oraz statystyczne, a także sondaże. Takie podejście prezentuje metoda IQM (ang. Information Quality Measuring) służąca do oceny jakości informacji w Internecie (Eppler, Muenzenmayer, 2002, s. 187-196). Metoda IQM została wykorzystana w dalszej części artykułu do badania jakości informacji witryn PWSZ. Poniżej przybliżono możliwe do analizowania obszary witryny oraz rodzaje uzyskanych danych $\mathrm{z}$ wykorzystaniem metod: automatycznych procedur, statystycznych oraz ankiet.

Pierwsza $\mathrm{z}$ wymienionych metod pozwala na stosowanie narzędzi/programów informatycznych celem analizy stron WWW pod kątem monitorowania, np.: wydajności serwisów, zgodności z wersją mobilną, a także optymalizowania i testowania witryny internetowej (Czerwiński, Krzesaj, 2018, s. 80). Do analizowanych elementów należą m.in.: kod HTML, metadane, zgodność $\mathrm{z}$ wersją mobilną, treść strony, linki, widoczność w mediach społecznościowych. Pozyskane z monitorowanych obszarów wskaźniki internetowe pozwalają na identyfikację określonych

\begin{tabular}{|c|c|c|c|c|c|}
\hline Zasady zarządzania & Integracja & Walidacja & Kontekstualizacja & Aktywacja & \multirow{4}{*}{ Jakość treści } \\
\hline Wymiary & \multicolumn{4}{|c|}{ Kryteria jakości } & \\
\hline Relewantność informacji & Kompleksowość & Dokładność & Przejrzystość & Zastosowalność & \\
\hline $\begin{array}{l}\text { Rzetelność } \\
\text { informacji }\end{array}$ & Zwięzłość & Zgodność & Prawidłowość & Aktualność & \\
\hline Zoptymalizowany proces & Wygodny & Terminowy & Sprawdzalny & Interaktywny & \multirow{2}{*}{ Jakość mediów } \\
\hline $\begin{array}{l}\text { Niezawodna } \\
\text { infrastruktura }\end{array}$ & Dostępna & Bezpieczna & Serwisowalna & Szybka & \\
\hline
\end{tabular}

Rys. 1. Ramy jakości informacji

Źródto: opracowanie własne na podstawie: Eppler, 2006, s. 68 
problemów jakościowych. Do oceny i doskonalenia określonych kryteriów jakości informacji przydatne są wskaźniki, takie jak: rozmiar strony, szybkość ładownia strony, atrybut ALT, zgodność z urządzeniami mobilnymi (tzw. responsywność), meta title, meta desctription.

Druga metoda oceny jakości informacji sprowadza się do analizy danych liczbowych odnoszących się do ruchu generowanego przez użytkowników na stronach, statystyk linków oraz innych danych ilościowych pozyskanych ze stron WWW. Analizie podlegają dane pozyskane $\mathrm{z}$ automatycznych rankingów serwisów WWW, a także monitorowania ruchu oraz zachowań użytkownika na witrynie. $\mathrm{W}$ procesie analizy danych przydatne stają się różne narzędzia, np. Google Analytics oraz rankingi serwisów: Alexa, Web of Trust (WOT). Do przykładowych elementów ocenianych przez te programy należą m.in.: odsłony witryny, zachowania użytkownika na stronie, źródła ruchu internetowego na witrynie. Generowane są m.in. takie wskaźniki, jak: całkowita liczba odsłon, średni czas trwania odsłony, ścieżka poruszania się użytkownika po serwisie, ruch bezpośredni, odesłania $\mathrm{z}$ innych stron (Czerwiński, Krzesaj, 2018, s. 81).

Wśród narzędzi służących do pomiaru jakości informacji na stronach WWW należy wymienić ankiety użytkownika. Dane uzyskane za pomocą ankiet dotyczą ocen dokonywanych przez użytkowników i mają głównie charakter jakościowy. Tego typu narzędzia są szczególnie przydane do pomiaru kryteriów odnoszących się do obszaru jakości treści witryny.

Wymienione narzędzia do monitorowania wydajności witryny mogą służyć do oceny jakości infrastruktury witryny (wymiar niezawodna infrastruktura) oraz kryteriów $\mathrm{w}$ wymiarze zoptymalizowany proces. Statystyki pochodzące $\mathrm{z}$ monitorowania ruchu oraz zachowań użytkowników witryn również wpisują się w elementy oceny wymiaru zoptymalizowany proces. Należy podkreślić, że wgląd do danych pomiarowych dotyczących ruchu posiadają głównie właściciele witryny. Użytkownicy witryny czy też konkurenci z danej branży dostęp do tych wskaźników mają ograniczony lub wręcz niewykonalny. Pomiar obszaru jakości treści jest możliwy z wykorzystaniem ankiet. Uzyskane wyniki pozwalają analizować m.in. kryteria dotyczące kompletności, poprawności czy zastosowalności dostarczanych informacji.

\section{Metoda badawcza}

W badaniu zaadaptowano metodę pomiaru jakości informacji M.J. Epplera i P. Muenzenmayera (2002, s. 187-196) służącą do oceny jakości informacji w Internecie. Autorzy metody IQM zaproponowani wykorzystanie różnych narzędzi informatycznych służących między innymi do monitorowania wydajności i ruchu na stronach WWW, a także badania opinii użytkowników. Użycie tych narzędzi pozwala na odpowiednie dopasowanie wskaźników internetowych do oceny wybranych kryteriów jakości informacji na stronach WWW. Badanie jakości informacji dotyczyło oceny trzydziestu czterech witryn internetowych Państwowych Wyższych Szkół
Zawodowych w Polsce, tj. wszystkich funkcjonujących w okresie badania (MNiSW, 2018).

Pomiar wskaźników internetowych z wykorzystaniem narzędzi informatycznych oraz ocenę pytań badawczych zawartych w kwestionariuszu ankietowym (tab. 1) przeprowadziła grupa 21 studentów II roku studiów stacjonarnych kierunku ekonomia Uniwersytetu Opolskiego. Założono, że studenci przeprowadzający badanie mają podobne potrzeby, co studenci studiujący w badanych uczelniach zawodowych. Studenci poszukiwali wybranych przez siebie informacji niezbędnych do realizacji aktualnych potrzeb informacyjnych w toku studiów. Badanie przeprowadzono w grudniu 2018 roku. Do oceny ośmiu kryteriów jakości informacji, należących do obszaru jakości mediów, wskazano wybrane wskaźniki internetowe, których pomiaru dokonano na podstawie automatycznych narzędzi internetowych. Natomiast do obszaru oceny jakości treści wykorzystano kwestionariusz ankiety. Badanie jakości informacji przeprowadzono w dwóch etapach.

Pierwszy etap dotyczył oceny kryteriów należących do wymiarów relewantność i rzetelność informacji, które mają związek $\mathrm{z}$ jakością treści. $\mathrm{W}$ tym celu opracowano kwestionariusz ankietowy składający się z ośmiu pytań szczegółowych odnoszących się do kryteriów: kompleksowość, dokładność, przejrzystość, zastosowalność, zwięzłość, zgodność, prawidłowość i aktualność. Pytania nie mają charakteru otwartego i pozwalają sprawdzić, czy dostępne informacje na witrynie spełnią określone kryteria jakości. Każde ze stwierdzeń zawiera objaśnienia w postaci wskazówek zawierających pytania pomocnicze z przykładami oraz wytyczne do oceny wyrażonej w skali punktowej Likerta (tab. 1). Pytania badawcze zostały dostosowane do jednej z potencjalnych grup użytkowników witryny - studentów. Zmiana grupy odbiorców, np. na kandydatów na studia lub na nauczycieli akademickich wymaga dostosowania pytań badawczych do danej grupy użytkowników.

Na podstawie odpowiedzi wyznaczono średnią wartość uzyskanej liczby punktów dla ośmiu kryteriów jakości dla trzydziestu czterech witryn według formuły:

$$
S R_{i}=\frac{\sum_{j=1}^{n} S R K_{j}}{n}
$$

gdzie:

$S R_{\mathrm{i}}$ - średnia wartość uzyskanej liczny punktów dla $n$ kryteriów,

$S R K_{\mathrm{j}}$ - średnia wartość uzyskanej liczny punktów dla j-tego kryterium,

$n$ - liczba kryteriów.

Syntetyczną miarę jakości informacji wyrażono jako procent maksymalnej do uzyskania liczby punków według formuły:

$$
S M_{i}=\frac{S R_{i}}{M a x S M} \times 100 \%
$$

gdzie:

$S M_{\mathrm{i}}$ - wartość syntetycznego miernika dla i-tej witryny, MaxSM - maksymalna do uzyskania wartość liczby punktów. 
Tabela 1. Zestawienie kryteriów oceny jakości informacji oraz przypisanych im pytań badawczych

\begin{tabular}{|c|c|}
\hline Kryterium jakości & Pytanie badawcze \\
\hline Kompleksowość & $\begin{array}{l}\text { Czy informacje na witrynie uczelni są kompleksowe/wyczerpujące? Wskazówki: - Czy portal uczelni zawiera } \\
\text { wszystkie niezbędne informacje do realizacji potrzeb informacji użytkownika (jak przykładowo: siatki studiów, } \\
\text { sylabusy przedmiotów, plany zajęć, pomoc materialna, stypendia itd.)? - Czy witryna zawiera pomocne dla } \\
\text { studentów informacje w postaci instrukcji, tutoriali, FAQ itp.? } \\
\text { Wytyczne do oceny punktowej pytania: } \\
\text { 5: Tak-zawiera wszystkie niezbędne informacje 2-4: Częściowo - tylko część informacji jest wystarczająca dla } \\
\text { potrzeb odbiorców witryny 1: Nie - informacje nie sa wyczerpujące }\end{array}$ \\
\hline Dokładność & $\begin{array}{l}\text { Czy informacje na witrynie uczelni przedstawiono precyzyjnie i dokładnie? Wskazówka: - Czy portal uczelni } \\
\text { zawiera wystarczająco szczegółowe informacje? } \\
\text { Wytyczne do oceny punktowej pytania: } \\
\text { 5: Tak - informacje na witrynie sa precyzyjne i dokładne 2-4: Częściowo - tylko część informacji jest precyzyjna } \\
\text { i dokładna 1: Nie - informacje nie sq wystarczająco szczegółowe }\end{array}$ \\
\hline Przejrzystość & $\begin{array}{l}\text { Czy informacje przedstawiono jasno i zrozumiale? Wskazówki: - Czy informacje na witrynie zaprezentowano } \\
\text { w nieczytelny sposób, np. zbyt rozbudowane zdania w opisie procesu rekrutacji na studia lub regulamin studiów? } \\
\text { - Czy poszukiwane informacje napisano zrozumiałym językiem bez zbędnych zwrotów formalnych i/lub } \\
\text { niezrozumiałych dla przeciętnego odbiorcy witryny? } \\
\text { Wytyczne do oceny punktowej pytania: } \\
\text { 5: Tak - przedstawione informacje sa jasne i zrozumiałe 2-4: Częściowo - tylko część informacji przedstawiono } \\
\text { w jasny sposób oraz napisano zrozumiałym językiem 1: Nie - informacje są niejasne bądź napisane niezrozumiałym } \\
\text { językiem }\end{array}$ \\
\hline Zastosowanie & $\begin{array}{l}\text { Czy informacje na witrynie są przydatne? Wskazówki: - Czy informacje zawarte na witrynie są gotowe do użycia } \\
\text { bez potrzeby ich transformacji lub konwersji (np. plany zajęć/informacje dla studentów są gotowe do wydruku)? } \\
\text { - Czy informacje są bezpośrednio przydatne do realizacji aktualnych potrzeb informacyjnych użytkownika (np. } \\
\text { informacje dotyczące: programu Erasmus+, pomocy materialnej, stypendiów i kredytów studenckich)? } \\
\text { Wytyczne do oceny punktowej pytania: } \\
\text { 5: Tak -wszystkie informacje są przydatne 2-4: Częściowo - tylko część informacji jest gotowa do użycia 1: Nie } \\
\text { - informacje nie są przydatne }\end{array}$ \\
\hline Zwięzłość & $\begin{array}{l}\text { Czy informacje przedstawione są w sposób zwięzły i obejmują tematykę zgodną z celem witryny? Wskazówka: } \\
\text { - Czy publikowane informacje nie są za bardzo rozbudowane lub posiadają niepotrzebne elementy? } \\
\text { Wytyczne do oceny punktowej pytania: } \\
\text { 5: Tak -wszystkie informacje przedstawione sa w zwięzły sposób 2-4: Częściowo - tylko część informacji jest za } \\
\text { bardzo rozbudowana lub posiada niepotrzebne elementy 1: Nie - wszystkie informacje przedstawione są za bardzo } \\
\text { rozbudowane lub posiadają niepotrzebne elementy }\end{array}$ \\
\hline Zgodność & $\begin{array}{l}\text { Czy witryna posiada treści zgodne z jej celem? Wskazówki: - Czy witryna uczelni nie zawiera zbędnych treści } \\
\text { wykraczających poza obszar działalności uczelni? - Czy kategorie umieszczonych w serwisie treści odpowiadają } \\
\text { ich głównym odbiorcom: studenci, pracownicy, kandydaci na studia? - Czy witryna zawiera reklamy, które nie } \\
\text { są związane z działalnością edukacyjną? } \\
\text { Wytyczne do oceny punktowej pytania: } \\
\text { 5: Tak - zawiera wszystkie informacje zgodne z celem witryny 2-4: Częściowo - tylko część informacji jest zgodna } \\
\text { z celem witryny 1: Nie - informacje nie są zgodne z celem witryny }\end{array}$ \\
\hline Prawidłowość & $\begin{array}{l}\text { Czy informacje w serwisie są zniekształcone lub błędne? Wskazówka: - Czy informacje na witrynie są stronnicze } \\
\text { bądź fałszywe (np. odnalezione informacje są nie aktualne przez co wprowadzają użytkownika w błąd)? } \\
\text { Wytyczne do oceny punktowej pytania: } \\
\text { 5: Tak - zawiera wszystkie informacje prawidłowe 2-4: Częściowo - tylko część informacji jest zniekształcona lub } \\
\text { błędna 1: Nie - większość informacji jest zniekształcona lub błędna }\end{array}$ \\
\hline Aktualność & $\begin{array}{l}\text { Czy na witrynie znajdują się aktualne informacje? Należy poszukać następujących informacji: - Czy jest } \\
\text { jasne kiedy wpis umieszczony na witrynie powstał (np. umieszczono datę wygenerowania informacji w dziale } \\
\text { aktualności)? - Czy zmienione lub zaktualizowane informacje opatrzono datą ich wygenerowania (np. } \\
\text { poprawiony plan zajęć)? - Czy umieszczono informację dotyczącą daty utworzenia i/lub aktualizacji strony/ } \\
\text { witryny (np. umieszczono aktualny rok w stopce strony)? } \\
\text { Wytyczne do oceny punktowej pytania: } \\
\text { 5: Tak - informacje na witrynie zawieraja daty ich powstania lub aktualizacji 2-4: Częściowo - tylko część informacji } \\
\text { na witrynie zawiera daty ich powstania lub aktualizacji 1: Nie - informacje na witrynie nie zawierają daty ich } \\
\text { powstania lub aktualizacji }\end{array}$ \\
\hline
\end{tabular}


Wartość miernika $S M_{\mathrm{i}}$ dla i-tej witryny nie uwzględnia ważności miar cząstkowych $\left(S R K_{\mathrm{i}}\right)$. Do tego celu można zastosować np. metodę punktową lub metodę GVP (Czerwiński, Krzesaj, 2014, s. 58-59). Wybór formuły wskaźnika, np. ważona średnia arytmetyczna, powodowałby przypisanie większej czułości tym wskaźnikom cząstkowym, które mają wyższe wartości wag. Istotność każdego kryterium wchodzącego w skład syntetycznego miernika wymaga określenia preferencji osób oceniających pytania badawcze. Uwzględnienie preferencji ekspertów i użytkowników prowadzi do subiektywizmu otrzymanych wag, jak też miary syntetycznej, co stanowi odrębny problem badawczy i nie zostało podjęte w niniejszym opracowaniu.

Powstałe syntetyczne mierniki pozwalają na utworzenie rankingu dla poszczególnych kryteriów jakości treści oraz rankingu jakości informacji na witrynach badanych podmiotów. Należy zaznaczyć, że ocena dokonana przez respondentów dotyczyła dostępnych informacji pozyskanych $\mathrm{z}$ obszaru witryny (strony głównej oraz wybranych podstron witryny).
Drugi etap badania wiązał się $\mathrm{z}$ pomiarem kryteriów należących do wymiarów zoptymalizowany proces i niezawodna infrastruktura, a mianowicie: wygoda, terminowość, sprawdzalność, interaktywność, dostępność, bezpieczeństwo, serwisowalność i szybkość. Wymienione kryteria mają związek z jakością mediów. Na tym etapie przeprowadzono pomiary wybranych 15 wskaźników internetowych $\mathrm{z}$ wykorzystaniem automatycznych narzędzi monitorujących witrynę, jak również ruch na niej. Wyboru miar do oceny przedstawionych kryteriów jakości informacji dokonano na podstawie pomiarów przeprowadzonych w lipcu 2018 dla witryn PWSZ. Badania pilotażowe potwierdziły możliwość wykorzystania uzyskanych miar (wskaźników internetowych) do oceny określonych kryteriów jakości informacji (Krzesaj, 2019). $\mathrm{W}$ badaniu wykorzystano darmowe narzędzia pomiarowe (część z nich posiada wersje odpłatne zawierające większą funkcjonalność): Mobile Website Speed Testing Tool (2019), Pingdom (2019), Dead Link Checker (2019), SEO Site Checkup (2019) i SEO Quake (2019).

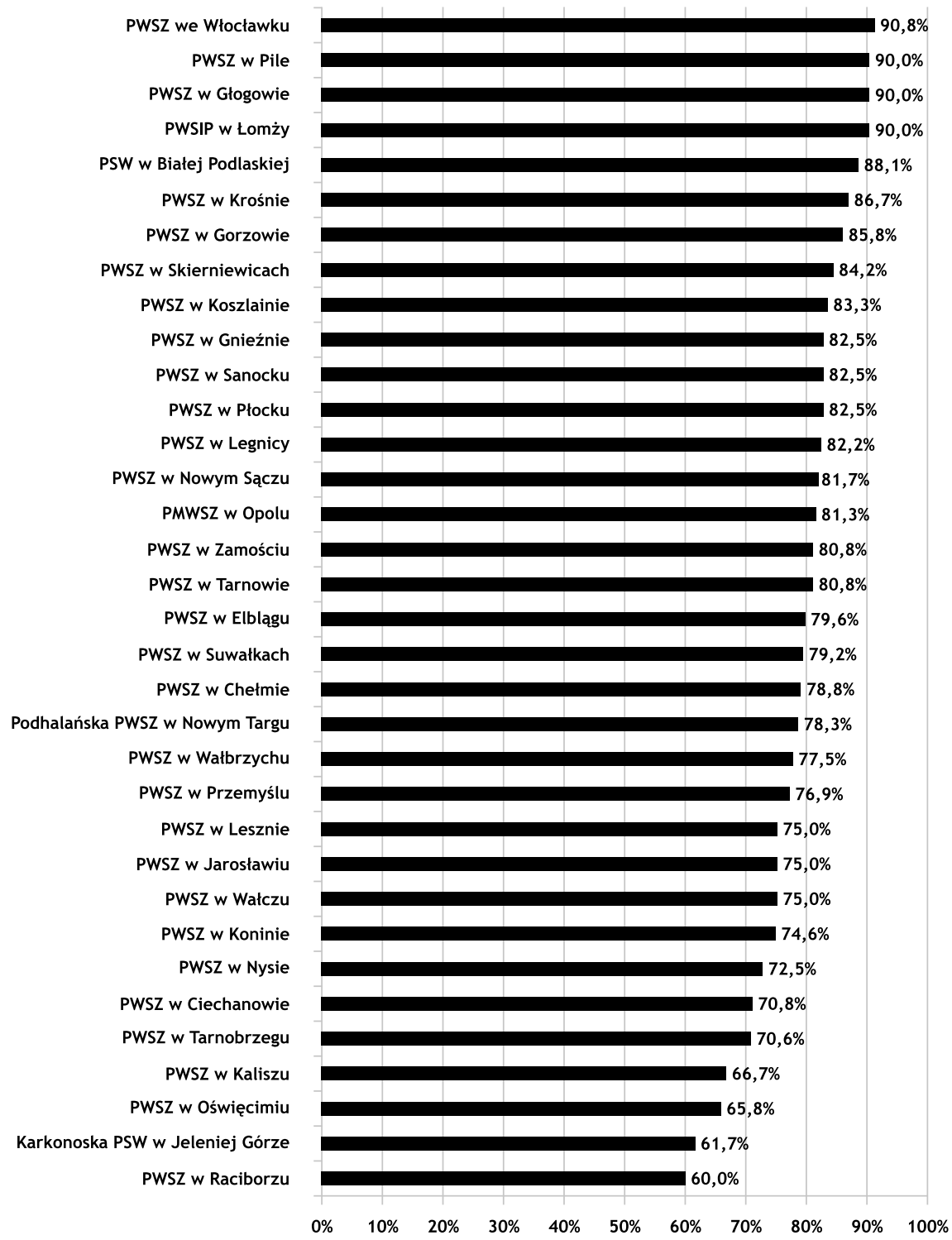

Rys. 2. Ranking witryn PWSZ w Polsce w obszarze jakości treści Źródło: opracowanie własne 


\section{Wyniki badań}

$\mathbf{R}$ ysunek 2 przedstawia syntetyczne mierniki dla badanych witryn w obszarze jakości treści. Pierwsze miejsce w ocenie respondentów zajęła witryna PWSZ we Włocławku z wynikiem 90,8\%.

Najgorzej wypadła strona PWSZ w Raciborzu, której wynik wynosi zaledwie $60,0 \%$. Średnia wartość miernika wynosi 78,9\%. Powyżej wartości średniej mieści się 19 szkół, natomiast poniżej 15 szkół.

Tabela 2 zawiera zestawienie mierników opisujących osiem kryteriów jakości informacji wraz z ich podstawowymi charakterystykami opisowymi. Przedstawione dane pozwalają na wyciągnięcie poniższych wniosków. Kryterium prawidłowość uzyskało najwyższą ocenę $87,8 \%$, a najniższa ocena $73,8 \%$ odnosi się do kryterium aktualność. Biorąc pod uwagę wartość rozstępu analizowanych miar, największa dyspersja wyników widoczna jest wokół miary opisującej kryterium kompleksowość $(66,7 \%)$, a najmniejsza dla miary kryterium prawidłowość $(30,0 \%)$. Uzyskane wartości wskazują na duże zróżnicowanie ocen w gronie respondentów. Rozkład ocen dla poszczególnych kryteriów cechuje się przeciętną zmiennością. Najniższy współczynnik zmienności dla miary kryterium prawidłowość wynosi 0,10, a najwyższy dla miary kryterium aktualność 0,21.

Wykres radarowy (rys. 3) przedstawia ogólną ocenę jakości treści postrzeganej z perspektywy potencjalnego użytkownika uczelni - studenta.

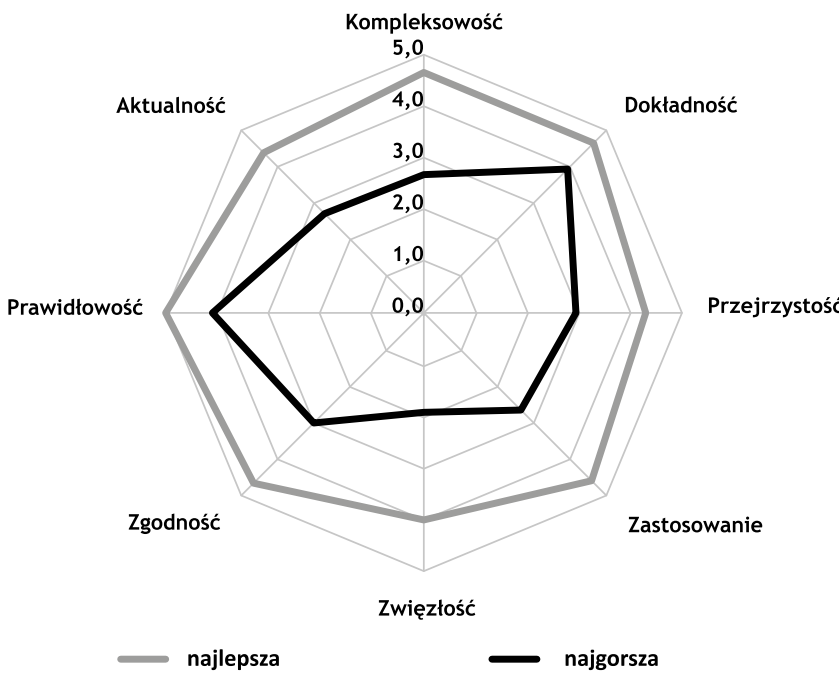

Rys. 3. Jakość treści dla najlepszego oraz najgorszego badanego podmiotu

Źródło: opracowanie własne

Uzyskane wyniki odnoszą się do dwóch wymiarów reprezentujących obszar jakości treści. Wykres prezentuje wartości mierników dla ośmiu kryteriów należących do najlepiej ocenionej (PWSZ we Włocławku) oraz najgorzej ocenionej (PWSZ w Raciborzu) witryny WWW.

Najmniejsze zróżnicowanie ocen wśród dwóch analizowanych podmiotów widoczne jest dla kryterium dokładność (rozstęp 13,3\%). Natomiast dla kryterium zwięzłość, kompleksowość, zastosowalność dyspersja ocen jest dość duża (rozstęp 40,0\%). Przedstawione rozbieżności w ocenie powyższych kryteriów mogą wynikać z różnych przesłanek, lecz ich identyfikacja wymaga dalszych pogłębionych badań.

Tabela 2. Charakterystyki opisowe mierników jakości treści na stronach PWSZ w Polsce

\begin{tabular}{|c|c|c|c|}
\hline Kryterium & Średnia & Rozstęp & $\begin{array}{c}\text { Współczynnik } \\
\text { zmienności }\end{array}$ \\
\hline Kompleksowość & $76,9 \%$ & $\mathbf{6 6 , 7 \%}$ & 0,19 \\
\hline Dokładność & $77,4 \%$ & $48,3 \%$ & 0,15 \\
\hline Przejrzystość & $75,8 \%$ & $46,7 \%$ & 0,17 \\
\hline Zastosowanie & $76,9 \%$ & $46,7 \%$ & 0,16 \\
\hline Zwięzłość & $78,9 \%$ & $60,0 \%$ & 0,17 \\
\hline Zgodność & $83,5 \%$ & $40,0 \%$ & 0,13 \\
\hline Prawidłowość & $\mathbf{8 7 , 8 \%}$ & $\mathbf{3 0 , 0} \%$ & 0,10 \\
\hline Aktualność & $\mathbf{7 3 , 8} \%$ & $53,3 \%$ & 0,21 \\
\hline
\end{tabular}

Źródło: opracowanie własne

Tabela 3 przedstawia wyniki badania jakości mediów (udział procentowy, wartość minimalna i maksymalna) oraz wskazuje obszar, którego pomiar dotyczy, to jest: obszar pojedynczej strony oraz całej witryny. Należy podkreślić, że wskaźniki zostały wygenerowane automatycznie. Analiza uzyskanych wartości wskaźników pozwala na określenie słabych punktów infrastruktury witryny. Badanym wskaźnikom przypisano symbole od $W 1$ do $W 15$.

Dostęp do własnego konta na portalu/portalach społecznościowych poprzez witrynę uczelni to wskaźnik internetowy związany z kryterium jakości informacji pod nazwą wygoda. Wśród przebadanych witryn (narzędzie SEO Site Checkup) 85\% (29 z 34) miało dostęp do minimum jednego $\mathrm{z}$ kont społecznościowych (facebook, twitter, instagram), co jest dość dobrym wynikiem.

Ocenę kryterium dostępność umożliwiają wskaźniki: obecność $\mathrm{w}$ domenie strony pliku sitemap.xml, liczba grafik bez atrybutu ALT oraz liczba linków uszkodzonych. Wśród przebadanych witryn (narzędzie SEO Quake) tylko 29\% (10 z 34) wykazało obecność wymienionego pliku. Plik sitemap.xml pozwala robotom wyszukiwarek dokładniej i skuteczniej indeksować treści danej witryny. Zawiera on między innymi metadane opisujące, jak często zmieniają się informacje na stronach, a także informacje o treściach trudnych do analizowania przez roboty indeksujące wyszukiwarek, np. opisy plików graficznych i wideo. Z kolei użycie tekstu alternatywnego pozwala na przedstawienie opisu obrazu podawanego jako wartość atrybutu ALT przy grafice wyświetlanej na stronie WWW (atrybut znacznika $<$ img >). Wśród przebadanych uczelni aż 41\% (14 z 34) 
Tabela 3. Wyniki pomiaru wskaźników internetowych opisujących wymiary zoptymalizowany proces i niezawodna infrastruktura

\begin{tabular}{|c|c|c|c|c|c|c|}
\hline $\begin{array}{l}\text { Kryterium } \\
\text { jakości } \\
\text { informacji }\end{array}$ & Wskaźnik internetowy & $\begin{array}{l}\text { Udział } \\
\text { procentowy }\end{array}$ & $\begin{array}{l}\text { Wartość } \\
\text { maksymalna }\end{array}$ & $\begin{array}{l}\text { Wartość } \\
\text { minimalna }\end{array}$ & $\begin{array}{l}\text { Pomiar } \\
\text { strony } \\
\text { gtównej }\end{array}$ & $\begin{array}{l}\text { Pomiar } \\
\text { witryny }\end{array}$ \\
\hline Wygoda & $\begin{array}{l}\text { W } 1 \text { - dostęp do konta na portalu/ } \\
\text { portalach społecznościowych (np. } \\
\text { facebook, twitter, instagram) }\end{array}$ & $85 \%$ & - & - & Tak & Tak \\
\hline \multirow{3}{*}{ Dostępność } & $W 2$ - obecność pliku sitemap.xml & $29 \%$ & - & - & Tak & Tak \\
\hline & W 3 - liczba grafik bez atrybutu ALT & $41 \%$ & - & - & Tak & $\mathrm{Nie}$ \\
\hline & W4 - liczba linków uszkodzonych & $94 \%$ & - & - & Tak & Nie \\
\hline Terminowość & $W 5$ - rozmiar strony & - & $14,92 \mathrm{MB}$ & $0,76 \mathrm{MB}$ & Tak & $\mathrm{Nie}$ \\
\hline Bezpieczeństwo & W 6 - wykorzystanie protokołu HTTPS & $41 \%$ & - & - & Tak & $\mathrm{Nie}$ \\
\hline \multirow[b]{2}{*}{ Sprawdzalność } & $W 7$ - obecność danych strukturalnych & $29 \%$ & - & - & Tak & $\mathrm{Nie}$ \\
\hline & $\begin{array}{l}\text { W } 8 \text { - współczynnik tekst/kod HTML } \\
\text { (udział procentowy: } W 8>25 \%)\end{array}$ & $21 \%$ & $47,72 \%$ & $9,16 \%$ & Tak & Nie \\
\hline \multirow{3}{*}{ Serwisowalność } & W9-znacznik meta title & $100 \%$ & 309 znaków & 14 znaków & Tak & Nie \\
\hline & W 10 - znacznik meta description & $76 \%$ & 202 znaków & 0 znaków & Tak & $\mathrm{Nie}$ \\
\hline & $\begin{array}{l}\text { W } 11 \text { - obecność analizatora ruchu na } \\
\text { witrynie }\end{array}$ & $76 \%$ & - & - & Tak & Tak \\
\hline \multirow{2}{*}{ Interaktywność } & W 12 - responsywność strony & $82 \%$ & - & - & Tak & Tak \\
\hline & W 13 - obecność znacznika meta viewport & $82 \%$ & - & - & Tak & Tak \\
\hline \multirow{2}{*}{ Szybkość } & $\begin{array}{l}\text { W } 14 \text { - czas ładowania strony głównej } \\
\text { w sieci } 3 \mathrm{G} \text { (udział procentowy: W } 14 \\
<=6 \mathrm{~s})\end{array}$ & $8 \%$ & $23,30 \mathrm{~s}$ & $4,25 \mathrm{~s}$ & Tak & Nie \\
\hline & $\begin{array}{l}\text { W } 15 \text { - czas ładowania strony głównej } \\
\text { (udział procentowy: } W 15<=3 \mathrm{~s} \text { ) }\end{array}$ & $74 \%$ & $5,65 \mathrm{~s}$ & $0,76 \mathrm{~s}$ & Tak & Nie \\
\hline
\end{tabular}

Źródto: opracowanie wtasne

nie posiadło opisów grafik na swojej stronie głównej witryny. Liczba linków uszkodzonych (broken links) to ostatni z analizowanych wskaźników odnoszący się do kryterium dostępność. Określa on liczbę linków, które nie działają (kod błędu 404 protokołu HTTP). Przynajmniej jeden niedziałający link na głównej stronie miało aż 94\% witryn ( 32 z 34). Biorąc pod uwagę przedstawione trzy wskaźniki, można stwierdzić, że dostępność treści badanych witryn jest dość słaba.

Wskaźnik internetowy rozmiar strony służy do oceny kryterium terminowość. Średnia wartość rozmiaru strony kształtuje się na poziomie 3,70 MB, wartość minimalna to $0,76 \mathrm{MB}$, a maksymalna $14,92 \mathrm{MB}$ (narzędzie Pingdom). Uzyskany wynik świadczy o zaniedbaniach związanych z optymalizacją elementów wyświetlanych na witrynie, a w szczególności grafiki. Duży rozmiar strony decyduje o jej prędkości ładowania (wskaźniki $W 14$ i W 15). Tak więc kryterium terminowość ma znaczący wpływ na kryterium szybkość.

Wśród przebadanych witryn uczelni jedynie 41\% (14 z 34) korzystało z protokołu HTTPS (narzędzie SEO Site Checkup). Stosowanie bezpiecznego protokołu ko- munikacyjnego HTTPS przez witrynę uczelni pozwala zapewnić poufność i integralność transmisji danych - wskaźnik ten służy do analizy kryterium bezpieczeństwo. Aktualne wytyczne tworzenia witryn zachęcają do ochrony połączenia użytkownika z witryną niezależnie od jej zawartości, co wpływa na bezpieczeństwo oraz zachowanie prywatności. Uzyskany wynik należy interpretować jako dość dobry, ponieważ protokół HTTPS stosunkowo od niedawna uznano za stały element budowy strony WWW, natomiast powszechnie używany jest przy większości witryn wymagających uwierzytelnienia (np. strony banków).

Kolejne analizowane wskaźniki to dane strukturalne oraz współczynnik tekst/HTML - oceniane kryterium jakości informacji to sprawdzalność. Wśród przebadanych stron WWW uczelni (narzędzie SEO Quake) jedynie $29 \%$ (10 z 34) korzystało z danych strukturalnych. Założono, że strona korzysta $\mathrm{z}$ danych strukturalnych, gdy używa przynajmniej jednego z formatów: Microdata, $R D F$, JSON-LD lub Open Graph. Dane strukturalne to standardy służące do klasyfikowania różnego typu informacji zamieszczanych na stronie i wyświetlanych dla 
użytkowników. Służą głównie wyszukiwarkom internetowym do rozpoznawania zawartości określonych fragmentów treści na stronie, a dzięki temu szybciej i trafniej docierają do odbiorcy. Współczynnik tekst/HTML odnosi się do ilości tekstu na stronie internetowej w porównaniu z kodem HTML na tej samej stronie internetowej. Według firm specjalizujących się w optymalizacji stron pod kątem wyszukiwarek internetowych stosunek treści do kodu HTML powinien mieścić się w zakresie od 25 do 70 procent. Przyjmując powyższe założenie, w takim zakresie mieści się tylko $21 \%$ uczelni ( 7 z 34), co stanowi relatywnie niski wynik. Średnia wartość współczynnika tekst/HTML dla trzydziestu czterech badanych podmiotów wyniosła $19,51 \%$; wartość minimalna - 9,16\%; a maksymalna $-47,72 \%$.

Wskaźniki internetowe: obecność analizatora ruchu na witrynie (Google Analytics), znacznik meta title oraz meta description pozwalają na ocenę kryterium serwisowalność (narzędzie SEO Quake). W przypadku pierwszego wskaźnika dostęp uczelni do informacji generowanych przez tego typu narzędzia jest istotny zarówno w kształtowaniu treści, jak i wyglądu witryny. Dostęp do wskaźników oferowanych przez narzędzia Google Analytics miało 76\% (26 z 34) uczelni. Pozostałe dwa wskaźniki dotyczą metainformacji. Znacznik meta title zawiera tytuł strony WWW, natomiast meta description - opis strony, który pojawia się w wynikach wyszukiwania. Wszystkie z badanych stron głównych uczelni posiadały tytuł. Standardy tworzenia stron zakładają, że tytuł nie powinien zawierać więcej niż 70 znaków. Wymóg ten spełniło $71 \%$ stron. Maksymalna liczba znaków wyniosła aż 309, natomiast wartość średnia to 79 znaków. Opisów stron nie umieszczono w przypadku aż $24 \%$ (8 z 34) badanych witryn. Znacznik meta description nie powinien zawierać więcej niż 300 znaków. W tym przedziale zmieściło się $97 \%$ stron (33 z 34). Uzyskane wyniki świadczą o przeciętnej dbałości o serwisowalność badanych witryn uczelni.

Interaktywność jako kryterium jakości informacji opisuje elastyczność procesu dostosowywania optymalnego interfejsu dla użytkownika witryny internetowej w przypadku dostępu do serwisu z urząazeń mobilnych. Wykorzystanie technik pozwalających na rozpoznawanie urządzeń przenośnych typu smartfon, tablet zwiększa dostępność do serwisu. Responsywność, znacznik meta viewport (opcja sterowania wymiarami i skalowaniem strony) to jedne $\mathrm{z}$ możliwych wskaźników pozwalających na weryfikację analizowanego kryterium. Wśród przebadanych witryn uczelni (narzędzia: SEO Quake, SEO Site Checkup) 82\% (28 z 34) posiada odpowiednie techniki pozwalające na dostosowanie optymalnego interfejsu w przypadku dostępu do serwisu $\mathrm{z}$ urządzeń mobilnych. Znacznik meta viewport w nagłówku badanych stron odnaleziono w 82\% (28 z 34) witryn uczelni. Ocena tego kryterium wypadła zatem dość dobrze.

Następnym dość istotnym wskaźnikiem internetowym jest czas ładowania strony - kryterium jakości informacji to szybkość. Średni czas ładowania stron na urządzeniach stacjonarnych dla trzydziestu czterech stron uczelni wyniósł: 2,55 s (narzędzie Pingdom). Czas ładowania strony głównej poniżej $3 \mathrm{~s}$ uzyskało $74 \%$ badanych witryn, co stanowi dość dobry wynik. W przypadku średniego czasu ładowania stron dla urządzeń mobilnych, który wynosi 9,21 s, można stwierdzić, że szybkość badanych stron jest względnie niska (narzędzie Mobile Website Speed Testing Tool). Czas ładowania strony głównej poniżej $6 \mathrm{~s} \mathrm{w}$ sieci $3 \mathrm{G}$ dla urządzeń mobilnych uzyskało jedynie $8 \%$ badanych witryn, co świadczy o słabym dostosowaniu do tego typu medium.

Podsumowując powyższą analizę badanych witryn PWSZ w Polsce, można wskazać na pewne problemy dotyczące procesów zarządzania treścią oraz obszaru infrastruktury. Zawodność infrastruktury witryn uwidoczniły kryteria dostępnossć i szybkosśc, a dość przeciętny wynik ukazują kryteria serwisowalność oraz bezpieczeństwo. Dość dobrze wypadły takie kryteria jakości informacji jak wygoda i interaktywność, natomiast niski wynik uzyskały kryteria sprawdzalność i terminowość, opisujące procesy zarządzania treścią. Zarówno obszar infrastruktury, jak i procesy zarządzania treścią wymagają wprowadzenia środków zaradczych przez zarządzających, autorów jak też działy IT uczelni.

\section{Karta wyników}

yniki uzyskane na podstawie dwóch etapów badania zaprezentowano za pomocą karty wyników (Eppler, 2006, s. 183). Na rysunku 4 obszar jakości treści reprezentują procentowe wyniki uzyskane na podstawie badania ankietowego. Drugi obszar, odwołujący się do jakości mediów (witryny internetowej), obrazują dane uzyskane $\mathrm{z}$ pomiaru 15 wskaźników internetowych. Karta wyników ukazuje aktualny poziom jakości informacji na trzydziestu czterech witrynach PWSZ w Polsce. Ma ona charakter migawkowy i obowiązuje w momencie przeprowadzonego badania i może być punktem wyjścia w ocenie działań zmierzających do doskonalenia jakości informacji, np. przy zmianie zakresu informacyjnego prezentowanego na witrynie. Dla każdej z badanych witryn możliwe jest stworzenie indywidualnej karty, a następnie dokonanie porównania na tle konkurencji.

Uzyskane wyniki oceny kryteriów jakości informacji zestawiono w odpowiadającym im czterech zasadach zarządzania, co wskazuje na możliwość ich wykorzystania $\mathrm{w}$ procesie doskonalenia jakości informacji w badanych serwisach internetowych (realizując odpowiednie działania, wykorzystując stosowne techniki oraz narzędzia). Cztery zasady zarządzania jakością informacji zaproponowane przez M.J. Epplera (zasada integracji, walidacji, kontekstualizacji oraz aktywacji) umożliwiają poprawę jakości informacji w serwisach internetowych. Przedstawione narzędzie może być wykorzystane do:

- identyfikacji ewentualnych obszarów do poprawy jakości informacji dokonywanej przez zarządzających witryną, 


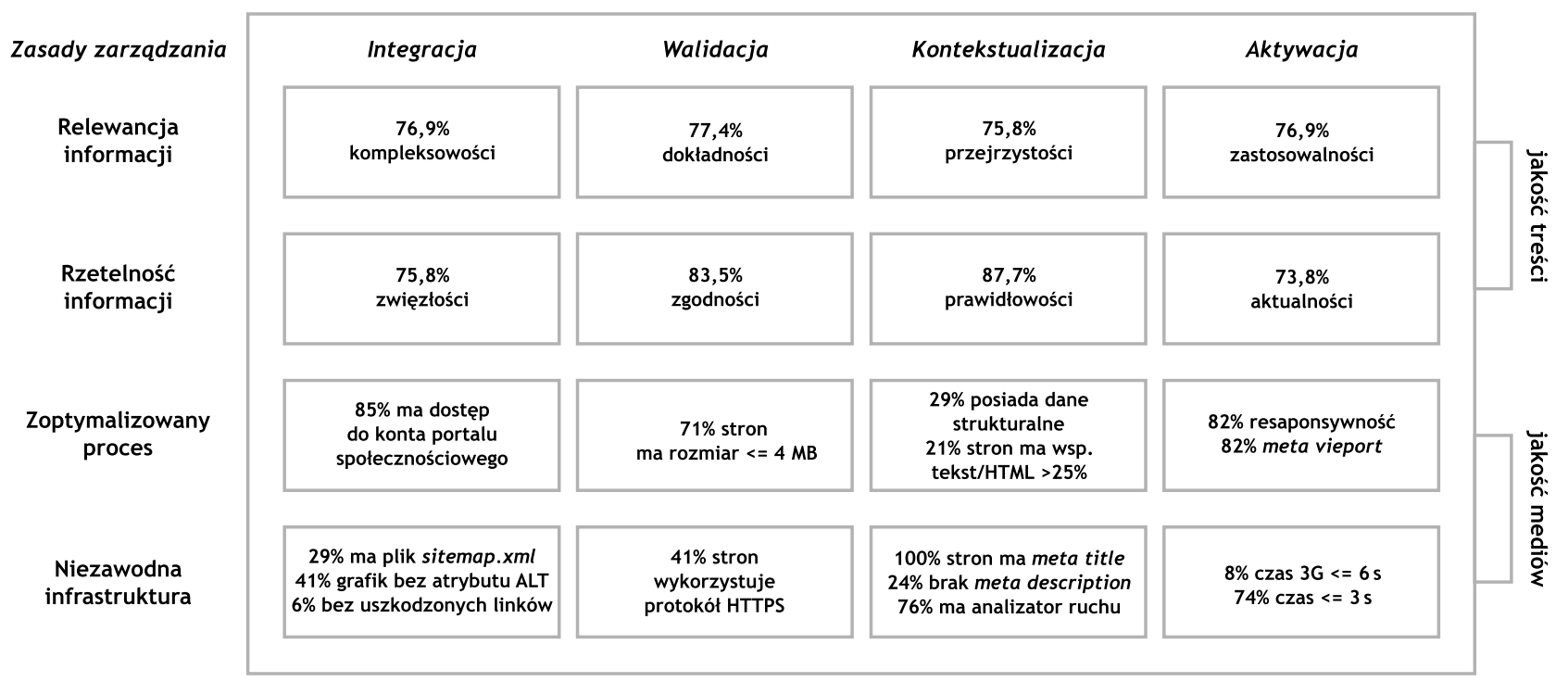

Rys. 4. Karta wyników oceny jakości informacji na witrynach PWSZ w Polsce

Źródto: opracowanie wtasne

- podjęcia działań mających na celu doskonalenie jakości informacji,

- monitorowania jakości informacji witryn internetowych w procesach zarządzania jakością informacji.

\section{Podsumowanie}

W artykule przedstawiono wyniki badań dotyczących oceny jakości informacji w serwisach internetowych Państwowych Wyższych Szkół Zawodowych (PWSZ) w Polsce. Ewaluacji poddano kryteria jakości informacji należące do dwóch obszarów ram jakości informacji M.J. Epplera, a mianowicie jakości treści z zakresu kształcenia i jakości mediów. Na podstawie uzyskanych syntetycznych mierników w obszarze jakości treści utworzono ranking witryn PWSZ w Polsce. Wartości mierników kształtują się w przedziale od 60,0 do $90,8 \%$, co wskazuje na dość duże zróżnicowanie jakości tego rodzaju informacji na witrynach tych uczelni. Następnie dokonano analizy kryteriów jakości informacji należących do wymiarów zoptymalizowany proces i niezawodna infrastruktura (obszar jakości mediów). Uzyskane rezultaty z obu obszarów zaprezentowano za pomocą karty wyników. Karta wyników określa aktualny poziom jakości informacji na badanych witrynach uczelni. Analiza badanych witryn PWSZ w Polsce identyfikuje pewne problemy związane $\mathrm{z}$ jakością informacji $\mathrm{w}$ obszarze infrastruktury (kryteria: dostępność, szybkość, serwisowalność, bezpieczeństwo) oraz procesów zarządzania treścią (kryteria: sprawdzalność, terminowość). Rozwiązanie powstałych problemów wymaga wdrożenia działań mających na celu doskonalenie jakości informacji. Do przykładowych działań można zaliczyć między innymi:

- uaktualnienie informacji (poprawa kryterium aktualność),

- dobór informacji dopasowanej do potrzeb ustalonej grupy odbiorców (poprawa kryterium kompleksowość),
- poprawę dostępności treści poprzez wykorzystanie mechanizmu responsywności strony (poprawa kryterium dostępność),

- optymalizację wydajności witryny, np. szybszy czas ładownia strony (poprawa kryterium szybkość),

- zapewnienie bezpieczeństwa witryny, a także poufności i integralności danych, np. poprzez wykorzystanie protokołu HTTPS (poprawa kryterium bezpieczeństwo).

Do ograniczeń przeprowadzonych badań w obszarze jakości treści należy wskazać subiektywizm odpowiedzi respondentów. Wynika to po pierwsze z faktu, że poszczególni odbiorcy informacji mają bardzo różne potrzeby informacyjne. Po drugie, ocena jakości treści na stronie zależy od kontekstu sytuacji, w której znajduje się odbiorca informacji w odniesieniu do rozwiązywanego zadania. Ponieważ dla jednego zadania, jakość tej samej informacji może być wystarczająca, podczas gdy dla innego niezadowalająca. Kolejny problem badawczy dotyczył zakresu pomiaru wskaźników internetowych w obszarze jakości mediów. Jedynie wyniki pomiaru pięciu wskaźników internetowych ( $W 1$, $W 2, W 11, W 12, W 13$ ) obejmują obszar całej witryny (strona główna wraz $\mathrm{z}$ podstronami). Pomiar pozostałych dziesięciu wskaźników ograniczony jest tylko do strony głównej witryny uczelni. Poprawę w liczbie przebadanych podstron witryny może przynieść proces automatyzacji pomiaru wskaźników internetowych, $\mathrm{np}$. w postaci wtyczki instalowanej $\mathrm{w}$ przeglądarce internetowej.

\author{
dr inż. Marcin Krzesaj \\ Uniwersytet Opolski \\ Wydziat Ekonomiczny \\ ORCID: 0000-0002-8585-9783 \\ e-mail: marcin.krzesaj@uni.opole.pl
}




\section{Bibliografia}

[1] Bernstram E.V., Shelton D.M., Walji M., Meric-Bernstam F. (2005), Instruments to Assess the Quality of Health Information on the World Wide Web: What Can Our Patients Actually Use? „International Journal of Medical Informatics”, Vol. 74, No. 1, pp. 13-19.

[2] Czerwiński A., Krzesaj M. (2014), Wybrane zagadnienia oceny jakości systemu informacyjnego $w$ sieci $W W W$, Wydawnictwo Uniwersytetu Opolskiego, Opole.

[3] Czerwiński A., Krzesaj M. (2018), Ocena jakości informacji w Internecie, Wydawnictwo Uniwersytetu Opolskiego, Opole.

[4] Dead Link Checker (2019), https://www.deadlinkchecker. com, access date: 20.02.2019.

[5] Eppler M.J., Muenzenmayer P. (2002), Measuring Information Quality in the Web Context: A Survey of State-of-the-art Instruments and an Application Methodology, Proceedings of the Seventh International Conference on Information Quality (ICIQ-02), pp. 187-196, https:// pdfs.semanticscholar.org/b7e0/4978992851255d26fd8a00b6673ea9f27f84.pdf, access date: 20.02.2019.

[6] Eppler M.J. (2001), A Generic Framework for Information Quality in Knowledge-intensive Processes, Proceedings of the Sixth International Conference on Information Quality, pp. 329-346, http://mitiq.mit.edu/ICIQ/ Documents/IQ\%20Conference\%202001/Papers/AGenericFramework4IQinKnowledgeIntenProc.pdf, access date: 20.02 .2019

[7] Eppler M.J. (2006), Managing Information Quality: Increasing the Value of Information in Knowledge-intensive Products and Processes, second edition, Springer, Berlin-Heidelberg-New York.

[8] Fuhr N. et al. (2007), Evaluation of Digital Libraries, „International Journal on Digital Libraries", Vol. 8, No. 1, pp. 21-38.

[9] Gagliardi A., Jadad A.R. (2002), Examination of Instruments Used to Rate Quality of Health Information on the Internet: Chronicle of a Voyage with an Unclear Destination, „British Medical Journal”, Vol. 324, No. 7337, pp. 569-573.

[10] Gkouskou K., Markaki A., Vasilaki M., Roidis A., Vlastos I. (2011), Quality of nutritional information on the Internet in health and disease, „Hippokratia”, Vol. 15, No. 4, pp. 304-307.

[11] Kaicker J., Borg Debono V., Dang W., Buckley N., Thaban L. (2010), Assessment of the Quality and Variability of Health Information on Chronic Pain Websites Using the DISCERN Instrument, „BMC Medicine”, Vol. 8, No. 59, pp. 1-8.

[12] Krzesaj M. (2019), Pomiar wybranych kryteriów jakości informacji na stronach WWW - studium przypadku, „Nierówności Społeczne a Wzrost Gospodarczy”, Nr 58, s. 329-339.

[13] Lee Y.W., Strong D.M., Kahn B.K., Wang R.Y. (2002), AIMQ: A Methodology for Information Quality Assessment, „Information \& Management”, Vol. 40, No. 2, pp. 133-146.

[14] MNiSW (2018), Wykaz uczelni publicznych nadzorowanych przez Ministra właściwego ds. szkolnictwa wyższego - Państwowe Wyższe Szkoly Zawodowe, https://www.gov. pl/web/nauka/wykaz-uczelni-publicznych-nadzorowanych-przez-ministra-wlasciwego-ds-szkolnictwa-wyzszego-panstwowe-wyzsze-szkoly-zawodowe, data dostępu: 07.02.2019 r.

[15] Mobile Website Speed Testing Tool (2019), https://testmysite.withgoogle.com/intl/pl-pl, access date: 20.02.2019.

[16] Pingdom (2019), https://tools.pingdom.com, access date: 20.02.2019.

[17] Saracevic T. (2004), Evaluation of Digital Libraries: An Overview, [in:] M. Agosti, N. Fuhr (eds.), Notes of the DELOS WP7 Workshop on the Evaluation of Digital Libraries, Padua, Italy.

[18] SEO Site Checkup (2019), https://seositecheckup.com, access date: 20.02.2019.

[19] SEO Quake (2019), https://www.seoquake.com/index. html, access date: 20.02.2019.

[20] Stvilia B., Gasser L.G., Twidale M.B., Smith L.C. (2007), A Framework for Information Quality Assessment, „Journal of the American Society for Information Science and Technology", Vol. 58, No. 12, pp. 1720-1733.

[21] Xie H. (2006), Evaluation of Digital Libraries: Criteria and Problems from Users' Perspectives, „Library and Information Science Research", No. 28, pp. 433-452.

[22] Zhang Y. (2010), Developing a Holistic Model for Digital Library Evaluation, „Journal of the American Society for Information Science and Technology", Vol. 61, No. 1, pp. 88-110.

\section{Application of M.J. Eppler's Quality Framework to Evaluate Information Quality of the Websites of the State Higher Vocational Schools}

\section{Summary}

The article presents the evaluation of information quality on the websites of the State Higher Vocational Schools (PWSZ) in Poland. The information quality framework proposed by M.J. Eppler was adopted as a diagnostic tool to identify gaps in information quality. The assessment was conducted from the user's perspective. Firstly, the ranking of the PWSZ sites in Poland was created. Secondly, the criteria for the quality of information in the website infrastructure were analysed. The conclusions result in a statement that most websites demonstrate a low level of information quality. The scope of synthetic measures ranges from $60.0 \%$ to $90.8 \%$ which indicates a wide variation in the information quality of the websites. In addition, some problems in the area of infrastructure and content management processes related to the quality of information have been identified. Finally, based on the results, a scorecard has been created. The scorecard can be used to identify and monitor the level of information quality on the websites. The information quality was assessed using a questionnaire and automated online tools.

\section{Keywords}

information quality, evaluation of information, information measurement 